\title{
Global limit for CFC emissions
}

Washington

INTERNATIONAL support is growing for a global cap on chlorofluorocarbon (CFC) emissions in order to avoid potentially serious climatic changes. So much has emerged from an informal meeting two weeks ago of the signatories of the Vienna Convention on Protection of the Ozone Layer. The meeting reached broad agreement on the need for controls. This could lead to an international protocol as soon as next summer.

Quite apart from the protection of the ozone layer which such an agreement would provide, an international agreement to restrict the emission of particular materials could be a precedent for similar accords on the regulation of other global pollutants including carbon dioxide, the chief candidate as culprit in the greenhouse effect.

The Vienna convention, the first to tackle a potentially global environmental problem, was signed in March 1985 by 21 countries; four more have since signed. Signatories agreed to hold informal workshops to discuss technical issues before the opening of formal negotiations on a control protocol, which must start in Geneva in December. At the final workshop at Leesburg, Virgina, US Ambassador Richard E. Benedick said that "there seems to be agreement that the world has entered a danger zone" and that almost all countries consider the risks "sufficiently serious as to warrant control actions".

CFCs are widely used as refrigerants, as solvents and in aerosol sprays. Although it is still uncertain how soon environmental problems due to CFCs may appear, all agree that their reaction products contribute to the breakdown of the stratospheric ozone layer. They are also "greenhouse gases" that could contribute to global warming. The worst offenders are CFCs 11 and 12; substitutes are available for many uses but often have disadvantages such as flammability and toxicity.

In 1985 an international study concluded, on the basis of two-dimensional atmospheric models, that continued releases of CFCs 11 and 12 at 1980 rates would reduce the ozone vertical column by a global average of 9 per cent, with reductions of up to 14 per cent in polar regions. But predictions are made difficult by the close coupling of CFC stratospheric chemistry and that of other pollutants. Observations of actual decreases in ozone have been hard to interpret, but there does seem to have been a 2 to 3 per cent decrease over the period $1970-80$.

Agreement on a control protocol seems imminent after a productive workshop in Rome but not all is sweetness and light. US participants at Leesburg were annoyed that the European Community and European industry still seem unwilling to contemplate further controls. The European Community has voluntarily adopted a cap on European CFC production capacity, but US critics point out that, with European production much less than the ceiling, production (and hence emissions) could continue to increase into next century before the cap would be effective.

In the United States, there has been a ban on the non-essential use of CFCs in aerosols since the 1970 s and the US government has tried to persuade others to follow suit. US government sources hint that, if Europe does not now come into line, the substantial European export trade in CFCs could be affected.

Significantly, the Alliance for Responsible CFC policy, a US industry consor-

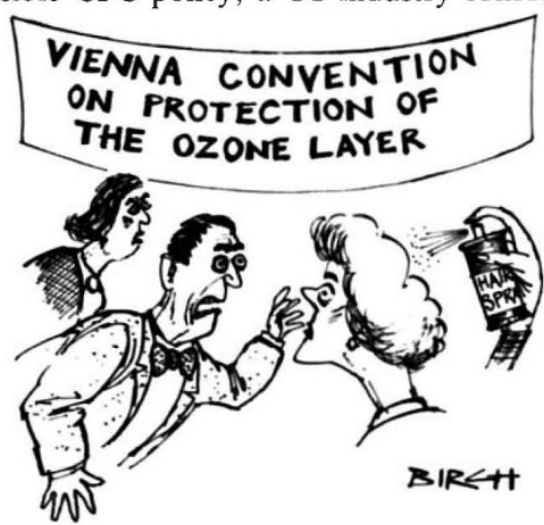

tium, has dropped its opposition to international controls, and now supports US attempts to negotiate an international protocol. The alliance has called for the US government to cooperate with other countries to fix a "reasonable global limit" for the growth of CFC production.

At Leesburg, the consensus was in favour of a cap on global emissions, rather than on the restriction of end uses. Much attention focused on a Canadian formula that would fix national quotas for $\mathrm{CFC}$ production as proportions of a global limit weighted 25 per cent for population size and 75 per cent for gross national product. British representatives at Leesburg (who were not formally representing their government's position) did not exclude the adoption of such a formula, but suggested that a change in the total that Europe could release at the same time might be politically too big a step in one year.

Observers were encouraged by signs of interest in global action from the Soviet Union, which for the first time gave figures on its CFC 11 and 12 production. Japan proposed a two-tier control system that woudl place immediate restrains on growth, followed by more controls as data become available with which to fix a safe emission limit.
British research funds Pound's fall an
embarrassment

THE recurring problem of foreign exchange once more threatens to beggar the Science and Engineering Research Council (SERC), Britain's principal source of basic science funding. According to the latest estimates (see figure) the council is likely to be a record $£ 18$ million in the red next year on international subscriptions of some $£ 70$ million, which make up nearly a quarter of its annual budget. This is the effect on British science of the falling oil price, which hit oil-rich Britain on the foreign exchange markets and pushed up SERC's international payments.

The council owes its international dues in Swiss francs (for the European Organisation for Nuclear Research, CERN), European Currency Units (for the European Space Agency, ESA), French francs, Belgian francs, Swedish kronor and Australian dollars. But the rub is that the British Treasury only pays the council in pounds sterling. In the now rare years when sterling is strengthening, the council can make a book profit on the exchange rate. But most of this must be paid back into Treasury coffers. Years of argument have resulted in agreement with the Treasury that the council can now save 4 per cent of its subscriptions ( $£ 0.7$ million) from one year to the next, or shift up to $£ 1$ million of any exchange rate profits into domestic expenditure. But this facility is nowhere near enough to meet the projected crisis in 1987-88.

In the current financial year, corrections made at the time of the public expenditure review in October 1985 plus the "Christmas present" of the then Secretary of State for Education and Science, Sir Keith Joseph, means the council expects to break even. But the corrections came late in the day, and were unpredictable largesse. Moreover, they only amounted to $£ 12$ million, whereas a 50 -per-cent larger correction seems necessary for next year. In its advice to government this summer, the Advisory Board for the Research Councils (which divides up the British government's basic science budget) recommended that SERC receive a $£ 9$ million adjustment for exchange rates, but even this is now out by a factor of two. Long-term research planning is thus made impossible, council officials complain.

In place of this uncertainty, the research council is seeking a new system of funding: a "variable cash-limited budget". This would be fixed partly in sterling, and partly in foreign currency. Thus the Treasury would suffer the exchange uncertainty, instead of "the whole thing being dumped on our plate", says SERC secretary Ashley Catterall. The Treasury, however, 


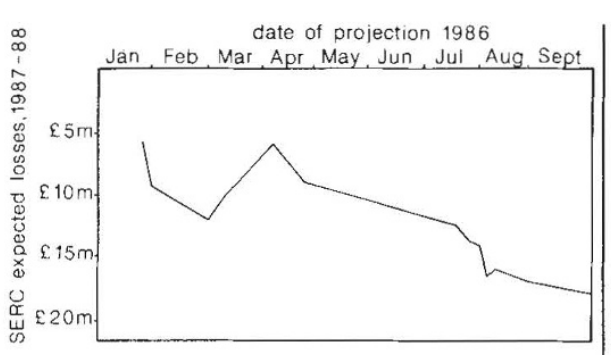

The UK Science and Engineering Council's increasing haemorrhage from its 1987-88 budget, with respect to plans put before the Treasury early in 1986, as the falling pound pushed up the cost of foreign-currency subscriptions to international programmes. Losses are now touching $£ 18$ million.

insists it will stick to the cash-limits it understands, in sterling, and refuses to insulate its payees from the consequences of their folly in making commitments in foreign currencies. Council sources perhaps unsurprisingly describe the argument for variable cash-limited budgets as "not getting very far". CERN, whose subscription is the council's largest, shows little sympathy; the issue is seen as Britain's self-inflicted wound, and one that Britain must sort out.

In October, the council will be considering to what extent any shortfall will have to be covered by cuts in studentships, or in research. If there are cuts, they will probably be at the margins of SERC's activity,

officials hint darkly. Training activities not directly connected with research such as the advanced course studentships, costing some $£ 10$ million or so annually may be threatened.

Moreover, there could be even more than $£ 18$ million to find because another international problem is looming for SERC: the extent to which the Treasury will wish to 'attribute' grants received by British researchers from the growing European Commission research programme. Under the strict interpretation of Treasury rules, the British science budget could be cut to keep a fixed level of science funding in Britain. At present little such 'attribution' appears to take place, but if European Commission research budgets increase dramatically next year (and 50 per cent is not unlikely), the Treasury seems likely to wake up to the possibilities and art.

This, however, would be seen as another self-inflicted wound. British scientists are highly successful at winning European funding, and certainly receive back more than the proportionate British subscription to the European Community. How much of the present European funding in Britain might be attributable to SERC? Dr Catterall considers it not in the council's interest even to "guesstimate". But the figure is likely to be in the region of millions of pounds. Robert Walgate

Solar power

\section{Australia joins the solar race}

Canberra

AN Australian team at the University of New South Wales, Sydney, reckons to be racing neck and neck with US laboratories towards the goal of an efficient silicon solar cell. But interest is now turning from the search for ever greater theoretical efficiency to the design of cells that will be economic in the field.

Australia has long been in the forefront of solar cell research, partly because of its latitude and its often cloudless skies but principally because of the remoteness of many of its communities. In the late 1970s, Australia was the largest market for solar cell applications.

Much of the recent running has been made by a group led by Dr Martin Green, itself part of the Microelectronics $\mathrm{Re}$ search Centre at the university, which has been singled out as one of ten centres of excellence by the federal government in Canberra. Last October, Green's group announced the design of a silicon cell with a conversion efficiency of just over 20 per cent, then the highest ever attained.

The essence of the Australian development is to etch $10 \mu \mathrm{m}$ microgrooves into the surface of a silicon wafer, which increases the efficiency of solar photon collection by internal reflection and reduces the chance of recombination between conduction electrons and electron holes by concentrating the formation of electronhole pairs near the $\mathrm{N}$-type silicon layer on the surface of the grooved structure. The grooves also increase the range-section area available for conduction by a factor of 3 , reducing the resistance of the cell.

Last year's record efficiency was obtained with a grooved cell coated with a thin layer of oxide, which appears to reduce lattice defects. Steps were also taken to reduce the distortion caused by the attachment of electrodes to the cell. Even so, the Australian record was eclipsed earlier this year, when a group at Stanford University in California announced the development of a cell with a conversion efficiency of 27.5 per cent, but only with the use of solar radiation concentrated on the active surface by a system of Suntracking Fresnel lenses.

Comparisons are difficult. Cells such as those developed at Stanford require steering systems, and can use only the direct component of solar radiation (on average, three-quarters of the total) while the costs are effectively determined by the Fresnel lenses. Green says that the two types of systems are at present roughly on a par. Concentrating solar cells are best

\section{Biology is the soft option in Albania}

Young Albanians are showing a distressing tendency to try to use higher education as a way of avoiding "productive labour", the youth daily Zeri $i$ Rinise complained recently. Instead of becoming "engineers, geologists and builders", they wish, the paper says, to become "lawyers, philosophers and biologists". The inclusion of biologists in the list is in marked contrast to other socialist countries, where biology is definitely production-orientated. (Do the scars of Lysenkoism linger yet, one wonders, in Stalinist Albania?)

This "petit bourgeois" mentality, the paper notes, is particularly reprehensible in that it affects workers and peasants, who want their children to find non-productive "intellectual jobs". It is understandable, Zeri $i$ Rinise notes sourly, if the children of doctors feel that they too should like to study medicine. But toilers in factory and field, it implies, should encourage their offspring to follow in their own, proletarian footsteps.

The issue is particularly important since Albanian university admission procedures are heavily weighted in favour of the children of workers and peasants - with the unspoken assumption that, in due course, they will return, with their new-won skills, to the ranks of the toilers. Nor is this weighting a merely symbolic one. According to the vice-rector of Tirana University, Hasan Mucostepa, this means that during the academic year 1985-86, some 50 per cent of all students at the university (Albania's principal higher educational institution) were the children of workers and peasants.

Vera Rich

suited for large-scale power production and excel in space, while direct solar panels of his own type are ideal in inaccessible places.

Green's team is now attempting to apply the lessons learned in the development of last year's cell to the world of mass production, where the high purity of the materials used will not be easily repeated. The work is supported by BP (British Petroleum) Solar Australia and the Sandia National Laboratories on behalf of the US Department of Energy.

Green reckons that his group is approaching a good compromise between cost and efficiency with a solar cell offering 18.8 per cent efficiency with a silicon wafer taken from BP Solar's production line. One important innovation has been the use of copper rather than silver contacts, which are embedded in slots cut by laser beams, well suited to mass production. It remains to be seen how best to scale up from the $2 \mathrm{~cm}$ square cells used last October to the $10 \mathrm{~cm}$ disks normally used.
Charles Morgan 